\title{
Vroue in die Sinoptiese Evangelies - méér as dekoratiewe karakters
}

\author{
Yolanda Dreyer \\ Departement Praktiese Teologie \\ Universiteit van Pretoria
}

\begin{abstract}
Women in the Synoptic Gospels - more than decorative characters

The aim of the paper is to show that the Synoptic Gospels represent different perspectives on Jesus and gender. From these perspectives Jesus' narrated vision on the role of the male disciples and the women is described in order to explore some implications of the three visions in Mark, Matthew, and Luke. The focus is on developing a comprehensive philosophy which attests to the full humanity and personhood of women, the equal value of men and women as persons, and the public acknowledgement of their value. The paper demonstrates that gender studies in biblical interpretation can contribute not only to the special interests of women, but also in a broader sense to society as a whole.
\end{abstract}

\section{INLEIDING}

Die doel van hierdie artikel is om die sentrale sienings van die drie Sinoptiese Evangelies, Markus, Mattheus en Lukas te beskryf en verduidelik. Elke siening verteenwoordig 'n ander perspektief op Jesus en geslag. Volgens die narratiewe model van Greimas, sou die manlike dissipels as die helpers van die protagonis Jesus gesien kon word. Die antagonis, die leiers van die Tweede Tempel in samewerking met die Romeinse politieke magte, verhinder die antagonis om sy sending te vervul. Die doel van Jesus se sending is om die waardes van die koninkryk van God te verwerklik teenoor dié van die heersende magte. Die "objek" van Jesus se sending is diegene wat voorheen van die tempel en dus ook God se teenwoordigheid, uitgesluit is. As die protagonis suksesvol sou wees, sou die "objek" in God se teenwoordigheid 
gebring word. Hierdie gemarginaliseerde mense is deel van die Israelitiese skare (oi

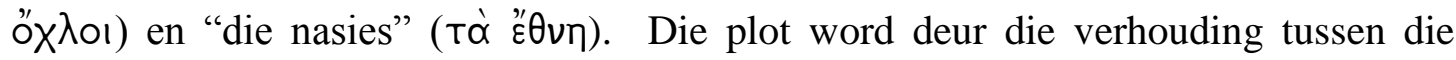
"hoofkarakters", die protagonis en sy of haar helpers, en die antagonis bepaal. Die rolle van die beskrywende ("by-") karakters is nie deurslaggewend vir die ontwikkeling van die plot nie (kyk Malbon 1992:29). Hulle verskaf tekstuur en help met die uitbeelding van die hoofkarakters (kyk Scott 1981:99).

Janice Capel Anderson (1992:112-134) identifiseer vier maniere waarop vroue-karakters in evangelienavorsing hanteer kan word. Een is om geslagsrolle en die verhoudings tussen die geslagte te beskryf deur op manlike en vroulike geslagsmerkers te fokus. 'n Ander moontlikheid is om te ondersoek hoe die teksgedeelte(s) gebruik kan word vir die bevryding van vroue uit manlike onderdrukking. 'n Derde manier is om die evangelies te lees met die oog op 'n rekonstruksie van die eintlike gedrag van mans en vroue in die antieke Meditereense samelewing. Die vierde fokus op die interpretasie-geskiedenis om vas te stel wat die eksegeet se siening oor geslag was. As die vier leesstyle by wyse van narratiewe kritiek toegepas word, kom twee tendense na vore. Die een is om vroue in die evangelies net as beskrywende karakters te sien. Die ander is om vroue te sien as die “objek" van die protagonis se sending. Ek meen egter dat die vrouekarakters 'n breër funksie in die narratiewe van die evangelies vervul. Dit het naamlik te doen met die verhouding tussen die manlike dissipels as helpers en vroue as deel van die "objek". Die fokus van die artikel is om hierdie verhouding in elke evangelie te verken. Eers sal die sentrale siening van die evangelie beskryf word. Jesus se vertelde siening oor die manlike dissipels en vrouekarakters sal beskryf word. Implikasies sal aangedui word.

\section{MARKUS-EVANGELIE}

\subsection{Markus se siening}

Die dood van Jesus aan die kruis staan sentraal in die Markusevangelie. Hierdie Jesus is die een wat weer sal kom (vgl Mark 8:38-9:1). Die kruis is vir Markus belangriker as die paroesie en hierdie klem vorm sy siening oor Jesus en verlossing (Kingsbury 1981:28). Best (1983:66) beskryf dit dat "[t]he death of Jesus broods over the entire Gospel". 
Sedert William Wrede ([1901] 1971; 1904:169-177) se verkennende werke het Markus-navorsers toenemend daarvan oortuig geraak dat die outeur met die verwerking van die materiaal, 'n eie literêre en teologiese werk geskep het. In die eerste deel van die Markus-verhaal (1:14-8:26) beskryf die verteller hoe Jesus sy dissipels uitkies (vgl Tannehill [1977] 1995:169-196; Best 1983:83-92), die mense leer, siekes genees en demone uitdryf (vgl Kingsbury 1981:29). Die tweede deel (8:27-16:8) skets Jesus se reis van Galilea na Jerusalem (vgl Malbon [1982] 1995:253-268). In Jerusalem ervaar Jesus verskriklike lyding wat uitloop op sy dood. Jesus bly nie dood nie - hy word opgewek en leef weer. Elizabeth Malbon (1995:258) beskryf dit soos volg: “Jesus' initial journey from Nazareth of Galilee to Judea, near Jerusalem (1:9), foreshows Jesus' final journey to Judea, to Jerusalem .... The ministry of the Marcan Jesus opens with Jesus' return to Galilee from Judea; the Marcan closing anticipates a like return."

Markus interpreteer die lewe van Jesus as die vervulling van OuTestamentiese beloftes (vgl Vorster 1981:62-72; Sanders \& Davies [1989] 1996:270271). Sy lewe is die hoogtepunt van God se betrokkenheid by mense. Albei figure, Johannes die Doper en Jesus van Nasaret, is 'n teken dat die eskatologiese tyd aangebreek het. Die era begin by Johannes en en sal eindig by die finale triomfantelike koms van Jesus. Die klem is op die bediening van Jesus. Mack (1988:355) stel dit soos volg: "The reason Mark wrote the story of Jesus in this way had little to do with the historical Jesus, much however, with the recent history of the Jesus movement to which Mark belonged."

Om Markus se voorstelling van Jesus as die "gekruisigde Christus" (Tatum 1999:59) te verstaan, moet verskeie samehangende temas in ag geneem word. Die tema van die "messiaanse geheim" loop deur die evangelie (Tatum 1999:59; cf Tuckett 1983). Jesus word voorgestel as die een wat sy ware identiteit en taak wil geheim hou.

Jesus orders demons, witnesses to his healings, and even his own disciples not to make him known $(1: 34 ; 3: 12 ; 5: 43 ; 7: 24,36 ; 8: 36 ; 9: 9,30)$. In Mark, the evangelist appears to be using the secrecy motif to show that Jesus has de-emphasized the more spectacular aspects of his ministry in favor of his vocation as the suffering "Son of Man" (8:31; 9:31; 10:32-34) and suffering "Son of God" (15:39). 
(Tatum 1999:59 - my beklemtoning)

Markus se denke kan van vroeg in die narratief reeds gevolg word (cf Matera [1988] 1995:289-306). Deurgaans gee hy leidrade oor wat met Jesus gaan gebeur. Een so 'n leidraad is die lot van Johannes die Doper (vgl Matera 1995:393-394). Wat met hom gebeur is 'n aanduiding van waarheen Jesus op pad is (vgl Mark 14:43-46). 'n Verdere leidraad is Jesus se interaksie met die Galilese en Judese élite. Jesus leer "soos een wat gesag het, en nie soos die skrifgeleerdes nie" (Mark 1:22). Die verhale dui op konflik tussen Jesus en die élite (vgl Dewey [1973] 1995:141-152). Die konflik gaan oor kultiese reëls en word deur die outeur opgelos met 'n beroep op "Christologiese" argumente (vgl Kuhn 1971:82-83). Volgens Markus is die élite die wat teen Jesus saamsweer (Mark 3:6) en hy laat Jesus verwys na die finale verwerping wat op hom wag (Mark 2:20).

Jesus het ook konflik met die Israelitiese skare (Mark 4:1-2) wat veronderstel is om uit sy "vriende" en familie te bestaan (Mark 3:20-21, 31-35) (vgl Kingsbury 1981:31). Vervreemding vind deurgaans plaas en loop uit op sy lyding en dood aan die kruis (Mark 15:25-41). Die manier waarop Markus sy kerugmatiese verhaal vertel, dui daarop dat hy die kruis as die sleutel sien tot die verstaan van Jesus se optrede en persoon. Dit het narratiewe implikasies (Kingsbury 1981:32). Verskeie narratiewe lyne vloei saam (kyk Via 1975:128-130). Volgens Kingsbury (1981:32) kan ten minste drie aangedui word:

- die storielyn soos dit na vore kom in die opsommingspassasies (Mark 1:32-39; 3:7-12; 6:53-56; 8:31; 9:31; 10:33-34 - vgl Kingsbury 1981:42);

- die geheim van Jesus se identiteit as die koninklike Seun van God;

- die onbegrip van die dissipels vir Jesus se missie.

Wanneer Petrus Jesus as "die Gesalfde” (ó Xpıotós) aanspreek (Mark 8:29), laat Markus Jesus antwoord met die "messiaanse geheim" formule (Mark 8:30). In die konteks van die Evangelie van Markus (ook oorgeneem deur Matt 16:22-23) is dit duidelik dat Petrus nie "ondergang" as 'n noodsaaklike voorspel tot die koms van die messiaanse verlossing sien nie. Die Markaanse Jesus (soos oorgelewer in Matt 16:21) verklaar egter dat die Seun van die Mens opgewek sal word na drie dae (Mark 8:31; 9:31; 10:33-34 - vgl Hos 6:1-2). Markus wys dat Petrus (Mark 8:29-30), die Twaalf (Mark 9:33) en die seuns van Sebbedeus (Jakobus en Johannes) (Mark 10:35-45), die 
"pilare" van die na-Pase Jesus-beweging in Jerusalem (Gal 2:9), nie verstaan wat God se bedoeling met die messias is nie. Die dissipels smag na grootheid en die seuns van Sebbedeus na koninklike eer. Die Markaanse Jesus is die vervulling van die profetiese woord (Jes 11:1-2, 3-4, 6) oor die messiaanse ideaal van diens.

Die Messiaanse ideaal bereik 'n klimaks in die derde voorspelling van Jesus se lyding. Dit vorm die draaipunt van die storielyn. Die seuns van Sebbedeus word deur

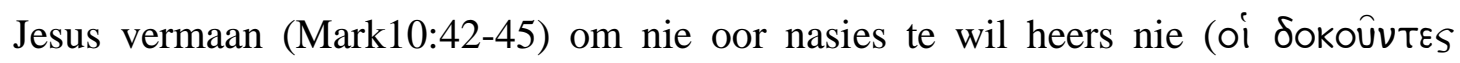

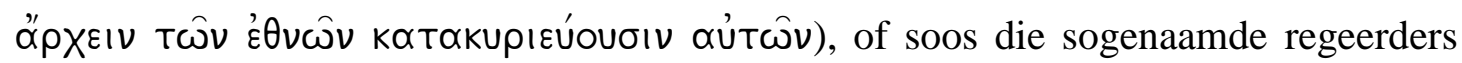

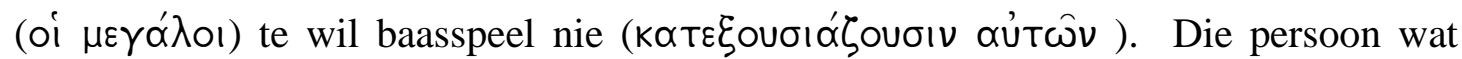

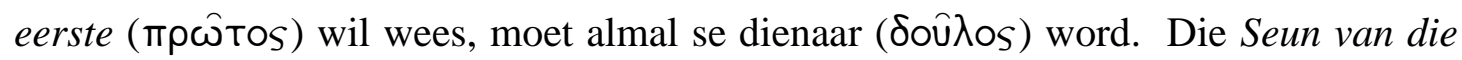
Mens (die triomfantelike messias) het gekom om te dien en nie om gedien te word nie

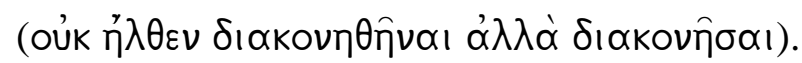

\section{$2.2 \quad$ Jesus en geslag}

Volgens Markus 16:7 sou die dissipels Jesus in Galilea ontmoet na sy dood. Die Galileërs was ook gebind aan tempeltradisies waarvolgens vroue en heidene nie in die direkte teenwoordigheid van God mag kom nie. Horsley en Silberman (1997:27) stel dit so: "From the evidence we gain from the gospels, from rabbinic literature, and from the scattered descriptions of Josephus, we know that the Galileans, too, clung passionately to ancestral traditions ..." Toe die voorhangsel in die tempel geskeur het met Jesus se dood, is direkte toegang tot God moontlik gemaak vir almal - vir vroue en heidene wie die verste van God af was. Die boodskap van Markus is die mees inklusiewe van al die evangelies. Kenmerkend van Markus is dat hy die manlike dissipels teenoor die vrouedissipels stel. Die volgende gedeeltes illustreer dit: die rol van Jesus se biologiese familie (Mark 3:11-14), die Siro-Fenisiese vrou (Mark 7:2430), die weduwee (Mark 12:41-44), die vroue by die kruis en die leë graf (Mark $15: 40-41 ; 16: 8)$.

Jesus se biologiese familie speel nie 'n positiewe rol in Markus nie. Sy ma, broers en susters tel nie onder sy volgelinge nie en verstaan nie sy boodskap nie. Hulle dink hy is mal (Mark 3:11-14). Jesus noem die wat die wil van God doen, sy moeder, broers en susters. Dit is opvallend dat "vader" weggelaat word. 'n Manlike partriargale figuur speel in die Markus-evangelie nie die tradisionele rol om toegang tot God vir vroue en kinders moontlik te maak nie. Jesus vervang die biologiese familie met 'n fiktiewe familie. Vir Markus is dissipelskap om geroep te wees deur 
Jesus, om familie en besittings agter te laat, om by Jesus te wees, om Jesus se "moeder, broer en suster" te wees, om God se wil te doen, om die geheim van die koninkryk van God te ontvang (Riches 2000:76).

In die tweede storie van die dubbele vertelling van die vermeerdering van brood (Mark 8:1-10) is die dissipels ongewillig om die gemengde bevolking in die heidense streek van die Dekapolis te voed (Mark 7:31) (vgl Klostermann [1926] 1971:129). Die eerste verhaal (Mark 6:30-44) speel af ten weste van die See van Galilea by Betsaida (Mark 6:45), met ander woorde Galilese (Israelitiese) gebied. Markus gebruik die Siro-Fenisiese vrou en haar dogter (Mark 7:24-30) om te illustreer dat die evangelie vir almal bedoel is. Die vrou is deel van die "objek" van Jesus se sending:

This story of a woman who wins aid by a smart answer is followed immediately by the healing of a man who is deaf and mute, or rather impaired of speech and who is enabled to speak rightly (7:31-37). This cure takes place in the largely Gentile area called Decapolis (7:31). The implication seems to be that the Greek woman's struggle with Jesus signaled a change in the scope of his mission.

(D’Angelo 1999a:139-140)

Die Siro-Fenisiese vrou is egter meer as net deel van die "objek" van Jesus se sending. Sy dra by tot 'n beter verstaan van die rol wat die manlike dissipels in Markus speel. Redaksie-kritiese werk op die dubbele vertelling oor die vermeerdering van die brood dui aan dat die eerste verhaal waarskynlik "JudeesChristelik" en die tweede "Hellenisties-Christelik" van oorsprong is. Markus gebruik die verhaal van die Siro-Fenisiese vrou as 'n skakel tussen die twee. Twee temas staan sentraal in die redaksie. Jesus se sending is inklusief: dit begin by Israel en ontwikkel om die heidense omgewing van die Dekapolis in te sluit. Die fokus verskuif van 'n Israelitiese tot 'n universele heidense konteks (kyk Pesch 1977:356; Van Aarde 1994:199-200). Die tweede tema is die dissipels se reaksie: hulle is nie gewillig om te deel in Jesus se sending in 'n inklusiewe konteks nie. Hulle verstaan nie wie Jesus werklik is en wat die wil van God beteken nie. Die storie van die SiroFenisiese vrou beklemtoon hulle onbegrip en ingesteldheid. 
Markus gebruik 'n vrou om die Groot Gebod (Mark 12:28-34) te illustreer (kyk Schmithals 1986:553). Die weduwee het alles wat sy gehad het aan God gegee (Mark 12:41-44). Elizabeth Malbon (2001:124-125) toon aan dat die weduwee behoort tot wat tradisioneel as die "objek" van Jesus se sending beskou is. Die rol wat die weduwee speel, help die leser om te verstaan wat die verteller verwag van die manlike dissipels as Jesus se “ideale volgelinge" (vgl Bultmann [1921] 1963:56-57). In tipies narratiewe terminologie verduidelik Malbon (2001:124-125) die interaksie tussen die karakters:

The enemies and exemplars are similar in their "flat", one- sided characterization; they differ in their negative or positive value as models for the reader. The unclean spirits and demons as well as most of the Jewish leaders, are "flat" and "bad". The minor characters of "little people", tend to be "flat" and "good". The 12 disciples, however, are "round", or multisided in their characterization, and also multivalent as models: they present both positive and negative models for the reader to follow or avoid. It would be inappropriate to focus on the "goodness" of the poor widow in opposition to the "badness" of the 12 disciples without also observing her "flatness" in contrast to their "roundness". All the Marcan characters work together for the sake of the Marcan story, its tellers and its hearers. This little story of the poor widow who gives "her whole life" is thoroughly integrated into the larger Marcan story of who Jesus is and what it means to be his follower.

Kenmerkend van Markus is dat hy die manlike dissipels teenoor die vroue volgelinge plaas (vgl Kinukawa 2001:178; Malbon 1986:109; Myers 1988:396; Swidler 1979:194-195; Dewey 1976:51, 132). Jesus stuur die twaalf dissipels uit om sy boodskap te verkondig (Mark 6:7-13). Sy volgelinge moet gewillig wees om hulle kruis te dra en hulle lewe vir die evangelieboodskap te gee (Mark 8:35). Die dissipels toon dikwels dat hulle nie verstaan waaroor die boodskap gaan nie.

- As Jesus verwys na sy kruisiging, protesteer Petrus en die ander dissipels (Mark 8:31-33) 
- Wanneer Jesus 'n tweede keer oor sy kruisiging praat, stry die dissipels oor wie van hulle die belangrikste is. Jesus gebruik 'n kind as voorbeeld. Wie gewillig is om soos 'n kind te word, is werklik belangrik (Mark 9:22-27). Woorde soos

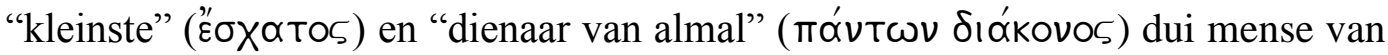
die laagste sosiale status aan. Sulke taal beskryf die gedrag van vroue. Vrouegedrag was om die laaste plek aan tafel in te neem, om ander te bedien, om te vergewe, om deurnis te hê, en om te genees (kyk Malina [1981] 1993:54).

- As Jesus 'n derde keer oor sy kruisiging praat, is die broers Jakobus en Johannes meer geïnteresseerd in 'n posisie van mag. Volgelinge van Jesus is egter slawe vir ander en gee hulle lewens vir ander (Mark 8:44-45). Dit gaan nie oor mag nie, maar oor diens. In die eerste-eeuse Mediterreense wêreld was dit vroue wat gedien het en geen mag gehad het nie.

- Terwyl Jesus verhoor word, beskuldig 'n vrou vir Petrus dat hy een van Jesus se volgelinge is. Hy ontken dit (Mark 14:66-72).

- As Jesus verloën word deur een van die twaalf en gearresteer word, vlug die dissipels (Mark 14:50). As Jesus gekruisig word, hardloop die manlike dissipels weg (vgl Tannehill [1977] 1995:402-403; Malbon 1983:32). Die vroue van Galilea bly by Jesus by die kruis (kyk Kinukawa 2001:175-176). 'n Vrou is die eerste getuie van sy opstanding en vroue ontvang die opdrag om die nuus te versprei.

Die vroue van Galilea volg Jesus tot by die kruis (Mark 15:40-41). Markus se woorde is: "hulle het hom gevolg en hom gedien".

The word "serve" reminds Greek-speaking people of menial work with two basic meanings: first, to wait on table, an activity usually done by male servants; and second, to provide care for, often in the sense of "women's work", taking care of the home and bringing up children. The word carries the general meaning to serve, especially in the sense of personal service rendered to someone by someone else. People desired to be served, not to serve. 
(Kinukawa 2001:182-183; vgl Moltmann-Wendel 1982:128;

Collins 1990:248, 252)

"Diens aan ander" is die taak van alle volgelinge van Jesus. Dit wil die gehalte van ander se lewens verbeter. Hierteenoor staan "regeer oor", wat net deur mans gedoen is. In Markus word "diens" slegs gebruik wanneer verwys word na vroue. Vroue is gewillig om te doen wat nodig is om Jesus se volgelinge te wees: hulleself te gee in diens. Hulle optrede bly 'n uitdaging aan die wat bly vashou aan partriargale gesag. Die implikasie is dat ' $n$ dissipelskap van diens die lewensgehalte van die geloofsgemeenskap sal verbeter (Kinukawa 2001:190).

\section{DIE MATTEUS-EVANGELIE}

\subsection{Matteus se siening}

Matteus se verhaal oor die lewe van Jesus bevat meer materiaal as Markus. Markus begin met die doop van Jesus. Matteus gaan terug tot by sy geslagsregister, geboorte en kinderjare (Matt 1-2). Die einde van Matteus gaan ook verder as dié van Markus. Markus voorspel dat Jesus weer in Galilea gesien sal word. Matteus berig oor die verskyning (Matt 28:16-20).

Volgens Kingsbury (1975:7-25; vgl Howell 1990:81-85) word die verhaal van die Matteus-evangelie in drie fases vertel. Matteus stel die leser voor aan Jesus Messias (Matt 1:1-4:16). In die tweede fase beskryf hy die openbare optrede van Jesus Messias (Matt 4:17-16:20). Die derde deel gaan oor sy lyding, dood en opstanding (Matt 16:21-28:20). Die oorgang van die een gedeelte na die volgende

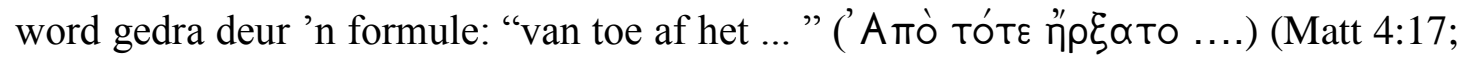
16:21). Davies en Allison (1997:58-72) oorweeg ander moontlikhede vir die strukturering van die Matteus-verhaal. C A Lohr (1961:403-435) deel Matteus byvoorbeeld in vyf dele. Hy gebruik die vyf toesprake as vertrekpunt en ontdek 'n konsentriese chiastiese struktuur (Luz 1985:17-18). Die formule wat hy gebruik as vertrekpunt, is die in Matteus 7:28-29; 11:1; 13:53; 19:1; 26:1: "toe Jesus klaar

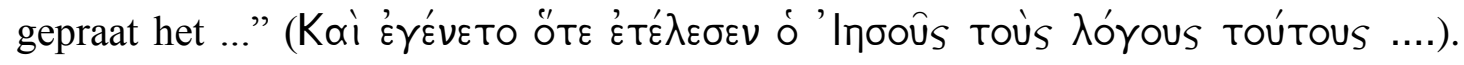
As hierdie struktuur aanvaar word, vorm Matteus 13 die middel van die evangelie. Die hooftema is die "koninkryk van die hemel (God)". "Koninkryk van God" het politieke konnotasies. "To speak of, to pray for God's Empire (Matt 6:10) in the 
midst of Rome's empire is to indicate profound dissatisfaction with Rome's empire. To call Jesus 'king' or 'emperor' presents a challenge to the Roman emperor" (Carter 2001:5). Jesus beklemtoon die kontras tussen die koninkryk van God en die van die keiser (vgl Carter 2000:36-40). Waar God genadig is, buit die Romeinse keiser mense uit. God is magtiger as die keiser. Die eer en mag van die tempelowerhede is afhanklik van die guns van Rome. Matteus se siening is dat hierdie leiers met Rome saamwerk. Die verwoesting van die tempel (Matt 22:1-10) deur Rome is God se straf (vgl Carter 2001:77).

In die lig van God se alternatiewe koninkryk is die karakterisering van Jesus as

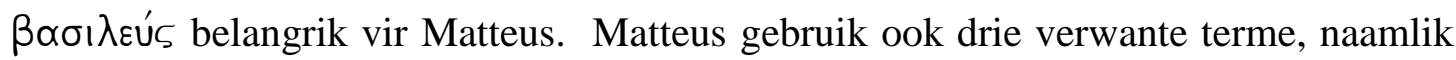
Kurios, Seun van Dawid en Messias. Dit fokus op Jesus se rol as die agent van God se genade. In Matteus hoort genade en geregtigheid saam (Bornkamm [1960] 1972:24-32). Volgens Matteus moet "ware geregtigheid" die geregtigheid van die Fariseërs oortref (Matt 5:20). Dit manifesteer wanneer God se liefde alle mense bereik, of hulle "waardig" is of nie. Matteus gebruik dikwels die name vir Jesus en die konsepte "om deernis te hê" en "om genade te hê" saam in die konteks van mense genees (kyk Duling 1978:392-410; 1992:99-116).

\subsection{Jesus en geslag}

Die Matteus-evangelie gaan oor die verstaan en doen van God se wil. Die outeur is bekommerd oor volgelinge van Jesus wat wil konformeer aan die reëls van die Fariseërs (vgl Minear 1974:93). In Markus verstaan die dissipels nie waaroor die evangelie boodskap gaan nie (Best 1977:387-389; Petersen 1978:78-79; Klauck 1982:26). In Matteus verstaan hulle, maar is nie in staat om dit te doen nie (Thompson 1970:16). Hulle kan nie onvoorwaardelik liefde betoon nie. Hulle is soos die Fariseërs.

Wanneer hy materiaal van Markus oorneem, verander Matteus die rolle van die dissipels en vroue (D’Angelo 1999b:176). In Matteus vaar die dissipels beter as in Markus. Hulle weet wie Jesus is, maar het moeite daarmee om God se wil te doen soos Jesus dit doen (vgl Held [1960] 1972:206). In Matteus is vroue nie dissipels nie, maar speel 'n ondersteunende rol (vgl Anderson 2001:43; contra Saldarini 2001a:161 nota 16). Saam met ander gemarginaliseerdes soos blindes, lammes en nie-Israeliete ontvang vroue die liefde van Jesus. Hy gee hulle toegang tot God se teenwoordigheid. Vroue is die passiewe ontvangers eerder as die aktiewe doeners 
(vgl Rosenblatt 2001:184). Hulle rol in die narratief is om die boodskap van Jesus, naamlik liefde vir alle mense, te demonstreer. Die dissipels is veronderstel om Jesus na te volg in woord en daad (Matt 10:1). Hulle behoort God se liefde aan gemarginaliseerdes te toon, maar slaag nie daarin nie. Die rol van vroue is om te toon hoe hulle faal (Anderson 2001:47).

$\mathrm{Na}$ die verwoesting van die tempel in $70 \mathrm{nC}$, het die Fariseërs die leidende groep geword (Neusner 1973, hfst 4; vgl Saldarini [1988] 2001b:147-151, 157-158). Hulle interpretasie van die Tora moes aanvaar word. Die volgelinge van Jesus het sý boodskap as die vervulling van die wet van God verstaan (Matt 5:17-20). Dit het

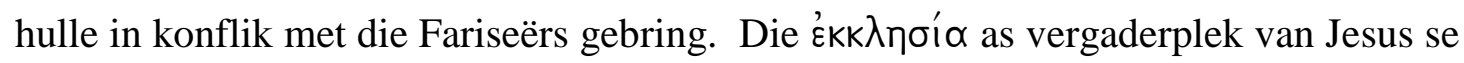
volgelinge, het almal ingesluit. Die tempel en бuvó $\gamma \omega \gamma \eta$ as vergaderplek van die seuns van Israel was eksklusief en toeganklik alleen vir aanvaarbare mans oor die ouderdom van twintig jaar (kyk Schrage 1963:178-202). Matteus waarsku die gemeenskap om nie terug te val in die leerstellings van die Fariseërs nie, maar om getrou te bly aan wat Jesus hulle geleer het (Matt 16:5). Hy het egter nie van hulle verwag om geheel en al met die gebruike van die Tweede Tempel te breek nie (Matt 17:24-27). As hy Markus se materiaal net oorgeneem het (kyk bv Mark 7:14-23, 10:1-12), sou dit tot ' $n$ breuk met die Israelitiese kultuur, soos verduidelik in Levitikus 11 en Deuteronomium 14; 24:1, 3, gelei het (kyk Kingsbury 1981:46). In Markus kontrasteer die lojaliteit van die vroue met die afvalligheid van die manlike dissipels (kyk Malbon 1983:29-48). In die ideologie van die Tweede Tempel was so-iets ondenkbaar. Alhoewel hy klem lê op inklusiwiteit, bly die Jesus van Matteus getrou aan die Tweede Tempel se sienings en voorskrifte. Matteus hou by Jesus se boodskap dat vroue nie van God se liefde uitgesluit word nie, maar vroue speel 'n ondergeskikte en ondersteunende rol.

Hierdie tweeledige visie kan gesien word in Matteus se geslagsregister en geboorteverhaal. Hoewel vroue by God se liefde ingesluit word, lê hulle primêre waarde steeds in geboorte gee en die opbou van die kinders van Abraham. Hulle word beskerm deur mans. Maria is ongetroud en swanger. Josef is gehoorsaam aan God en neem haar as sy vrou ten spyte van haar "skande". In Matteus is Josef die hoofkarakter. God praat met hóm. Matteus oorreed sy lesers dat Maria tog aanvaarbaar is om te help met die bou van die nasie. Hy sluit verder vier “onaanvaarbare" vroue by die geslagsregister in (Matt 1:1-18): Tamar (Gen 38), 
Ragab (Jos 2), Rut en Batseba, die vrou van Uria (2 Sam 11-12). Hierdie vroue, en veral Maria, word die “objek” van God se liefde.

'n Ooreenstemmende siening word gevind in hoe Matteus Markus se materiaal oor die vrou met bloedvloeiing en Jaïrus se dogter verander (Mark 5:21-42; $\dddot{\alpha} \rho \times \omega \nu$ in Matt 9:18, 23) om 'n ander boodskap oor vroue oor te dra (Matt 9:18-26). Hy verander menstruele bloeding tot bloeding in die algemeen. Hy laat die ouderdom van die dogter (12 jaar) weg. Op twaalf was 'n jong vrou seksueel volwasse en reg vir die huwelik. Volgens Levitikus (15:19-30) is vroue wat menstrueer, onrein en mag nie aangeraak word nie. In Markus word Jesus aangeraak deur 'n vrou wat menstrueer. In Matteus gaan dit nie oor menstruasie nie en die vrou neem ook nie die inisiatief nie. Sy is slegs die een wat Jesus se liefde net soos alle ander onrein mense ontvang (kyk D’Angelo 1999b:175).

Matteus verander Markus se Siro-Feniesiese vrou wat in die gebied van die Dekapolis was (in Markus het Jesus die grense oorgesteek) na 'n Kanaänitiese vrou (Matt 15:21-28) in 'n Israelitiese omgewing (Matt 15:29-31) (D’Angelo 1999b:175). “Kanaäniet" verwys na die plaaslike (heiden) mense (D’Angelo 1999b:175; Humphries-Brooks 2001:142). Dit is opmerklik dat hierdie heidense vrou Jesus as

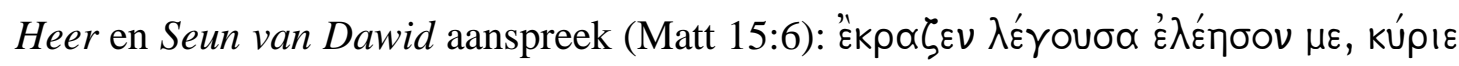
viòs $\Delta$ aví́. Hiermee kry die verteller die leser se aandag. Dan plaas hy vroue langs heidene as die ontvangers van die liefde van Jesus, Seun van Dawid. In Matteus fokus Jesus op die "verlore skape uit die huis van Israel" (Matt 10:6). Jesus se sending wil die profetiese idee van die pelgrimsreis van "alle mense" ( $\pi \dot{\nu} v \tau \alpha$ T⿳亠口

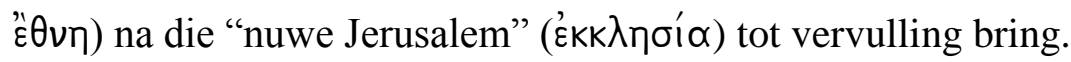

Proseliete is drie keer getoets voor hulle aanvaar is tot die Israelitiese geloof. Rut is ' $n$ voorbeeld hiervan. Matteus vertel die storie van die Kanaänitiese vrou volgens die model van Rut se verhaal (kyk Jackson 2001). Die proseliet word twee keer verwerp. Rut word teruggestuur na haar eie land. Jesus sê aan die Kanaänitiese vrou dat hy gekom het vir die "verlore skape van Israel" (Matt 15:24). Albei vroue dring drie keer daarop aan dat hulle die God van Israel aanvaar. Hulle slaag die toets. In Markus is die vrou 'n aktiewe agent, terwyl sy in Matteus die passiewe ontvanger van Jesus se liefde is.

In Markus (10:35-40) maak die seuns van Sebedeus aanspraak op ereposisies, een aan Jesus se linkerkant en die ander aan sy regterkant. In Matteus is dit hulle ma 
wat hierdie posisies vir hulle wil hê (Matt 20:20-23). In die kultuur is waarde en eer aan 'n vrou toegeken as sy geboorte gegee het aan seuns (kyk Malina 1993:48-55). Matteus sit die ma op haar plek (D'Angelo 1999b:174). Hy doen dit deur haar by die kruis te plaas waar sy sien dat dié aan Jesus se linker- en regterkant nie eerbare mense is nie (Matt 27:38, 56). In die koninkryk van God gaan dit nie om eer nie. Markus ontmasker egter nie 'n vrou nie. Hy wil die twee manlike dissipels, die seuns van Sebedeus, kritiseer.

'n Soortgelyke tendens kan gesien word in Matteus waar Jesus praat oor egskeiding. In die tradisie van die evangelie word egskeiding met owerspel gekoppel. Owerspel (порvєі́) gaan egter nie net oor buite-egtelike seks nie. Dit verwys ook na verbode verhoudings met onder andere "gebruikte" (geskeide en verkragte) vroue. "Porneia is frequently interpreted as those sexual relations between kin forbidden by Leviticus. As widely noted, one of the texts from Qumran does list forbidden relations as fornication, along with polygamy and sex with a menstruating woman (Damascus Document 5:8-9), and Paul applies the word to such relations (1 Cor 5:1)" (D’Angelo 1999b:178). Matteus verander die moontlikheid in Markus (10:12) dat vroue ook skeibriewe kan bekom na die tradisionele posisie dat net mans kan skei (Matt 5:29-32; 19:2-12) (vgl Davies 1993:132). Wat Elaine Wainright (1991) gesê het in verband met die Kanaänitiese vrou, kan ook gesê word in reaksie op Matteus se hantering van die egskeidingstekste: "A silent voice is further silenced" (Wainright 2001:127).

In vergelyking met Markus, is die prentjie van vroue in Matteus "minder gelyk”, maar “meer kompleks” (D’Angelo 1999b:176). In Matteus tree vroue nie onafhanklik op nie. Hulle word ingesluit in die groep wat die "objek" van Jesus se liefde vorm. Hierdie "inklusiwiteit" van Matteus beteken egter nie dat Jesus enige grense oorskry het nie.

To be sure, Matthew treats women cordially and ascribes to them a wide variety of roles: wife, mother, servant, mother-in-law, prostitute, etc. But these are precisely the roles which we would expect in a text emerging from a patriarchal community .... Women make their needs known, sometimes with an audacity which is itself praised (15:21-28). They are sometimes in need of help, for themselves or for someone dependant on them. They ask for it and thus give evidence of their faith. Their example 
itself becomes a challenge to Matthew's audience to learn faith from those, he implies, whose status would seem to to preclude such privilege ... It would seem me that this process not only subordinates the female to the male, but actually excludes the female from egalitarian participation.

(Deutsch 2001:108, 112)

Anderson (2001:44) meen die rolle van vroue in Matteus "strain the boundaries of the gospel's patriarchal worldview. Yet female gender renders the exemplary behavior of women as more of an achievement and heightens contrasts with male characters. It ensures for women subordinate and auxiliary positions."

\section{DIE LUKAS-EVANGELIE}

\subsection{Lukas se siening}

Die sinoptiese evangelies is nie feitlike weergawes van die lewe van Jesus nie, maar "kerugmatiese stories" (kyk Marshall [1970] 1992:21-52; Green 1997:14-20). Lukas

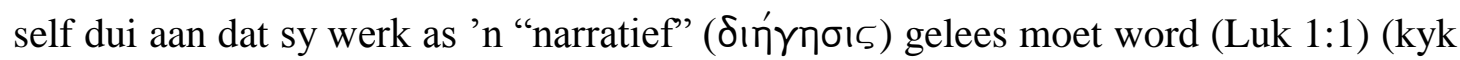
Esler [1987] 1996:224 nota 2; Green 1997:1-6). Dit is die "korrekte wyse"

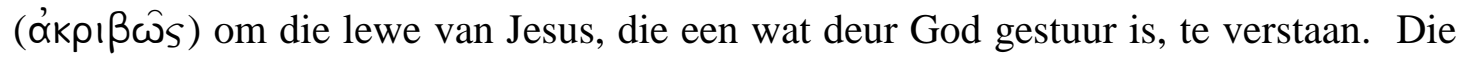
evangelie is aan 'n spesifieke persoon, Teofilus, gerig, asook aan die geloofsgemeenskap waartoe Lukas behoort (kyk Esler 1996:24-45) - vandaar die voornaamwoord "ons" (Luk 1:2 - kyk Fitzmyer 1989:16-22), veral in die sogenoemde “ons-passasies” (kyk Robbins 1975:5-18, 1978:215-242; Bonz 2000:170-173). Die doel van sy skrywe is om te wete te kom: “... dat die dinge waaroor u onderrig is,

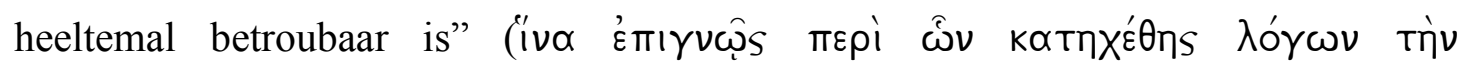

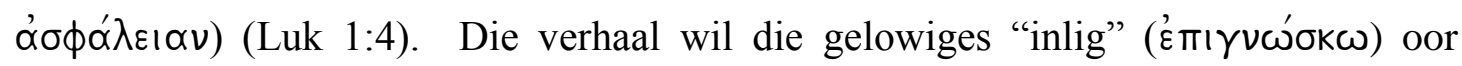
"betroubare kennis" ( $\left.\alpha \dot{\sigma} \sigma \alpha \alpha^{\prime} \lambda \varepsilon \propto \alpha\right)$ van God se werk in Jesus wat hulle "geleer" $\left(K \propto \operatorname{T\eta } \chi^{\prime} \dot{\omega} \omega\right)$ is.

Die wyse waarop Lukas sy materiaal organiseer, is van belang. Die kindheidsverhale en opstandingsverhale is eie aan Lukas. Hierdie verhale vorm die begin en die einde van sy narratief (Luk 1-2; 24). Die struktuur volg Markus, terwyl $\mathrm{Q}$ in twee gedeeltes aangetref word (Luk 6:20-7:35; 9:51-18:14). Die paasfees en verhoging vorm die klimaks van die verhaal. Lukas, Markus en Matteus deel die 
tradisie van die "paas-kerugma" van die vroeë kerk (kyk ook 1 Kor 15:3-5) (Kingsbury 1981:94).

Die Lukas-evangelie is selfs meer uitgebreid as Matteus (Kingsbury 1981:96). Lukas begin met die geboorte van Johannes die Doper vóór Jesus se geboorte (Luk 1:5-25), waar Matteus met Jesus begin. Aan die einde van sy verhaal gaan Lukas ook verder as die opstanding tot by die hemelvaart van Jesus (Luk 24:50-53). Na die inleiding stel Lukas die leser bekend aan Johannes die Doper, die een wat die koms van die Messias van God voorspel (kyk Goulder 1989a:270-281; Fitzmeyr 1989:86116; Geyser 1956:70-75; Robinson 1957-1958:263-281; Allison 1984:256-258), en dan stel Lukas Jesus, die Messias, aan die leser voor. Daarna volg Jesus se openbare optrede. Hy reis van Galilea af (Luk 4:14-9:50) na Jerusalem (Luk 9:51-19:44) (kyk Goulder 1989b:453-483; 1983:561-568; Reicke 1959:206-216; Selin 1978:100-135). In Jerusalem onderrig hy mense in die tempel en dan volg sy lyding, dood, opstanding en hemelvaart (Luk 22:1-24:53). Die reis na Jerusalem vorm die storielyn.

Karakterisering dra by tot die storielyn. God, hoewel onsigbaar, is die hoofkarakter, die een wat elke aksie stuur (Knight 1998:58; vgl Green 1997:50). Die ander karakters in die verhaal help of hinder God se doel (ßoùń тoû $\theta \varepsilon \circ u ̂)$. Jesus en sy getuies, die protagoniste, is met God se doel besig is. Die Israelitiese leiers en die wat hulle ideologie volg, is die antagonis wat teen God se doel ingaan. God se doel is om die mensheid te red. Dit kan in twee kontekste gesien word: vir Israel is die langverwagte hoop op verlossing deur God se Messias vervul en die heidene word nou ingesluit in God se verlossingswerk. Lukas begin met Israel (vgl Tiede 1988:2426) en verskuif geleidelik die aandag na die heidene. Hy begin met die bekende, die hoop van Israel. Daarby voeg hy 'n nuwe idee: dat die verlossing ook vir ander, vir almal is. In die woorde van Hans Conzelmann ([1954] 1973:9-11) behels dit die verskuiwing vanaf die "Zeit Israels" na die "Zeit des Wirkens Jesu". Die wortels hiervan kan teruggevind word in die profetiese tradisie van Israel (Green 1995:24).

\subsection{Jesus en geslag}

Die vervulling van Israel se hoop sluit die profetiese belofte in dat gemarginaliseerdes aanvaar sal word (Luk 4:17-19; vgl Jes 61:1-2). Lukas skets Jesus as een wat die armes en onderdruktes bedien. Jesus gaan teen die strukture in wat mense gemarginaliseer. Dit bring hom in konflik met die heersende magte. In sowel die 
konteks van Israel en van die heidene word vroue ingesluit in Jesus se interaksie met die marginaliseerdes.

Die verhaal van die sondige vrou (Luk 7:36-50) in die Farisëer se huis is 'n voorbeeld van 'n vrou wat ingesluit word in die konteks van Israel. Die laaste verse (Luk 7:48, 50) wys dat dit 'n "quest" verhaal is (vgl Tannehill 1986:111): die vrou soek na vergifnis. Die verhaal daag die konvensionele idees van die gasheer, die Fariseër, uit. Hy hoort tot die groep wat die Tora onderhou en nie met sondaars omgaan nie. Die vrou, 'n erkende sondaar, betree sy huis en gedra haar op 'n manier wat ongehoord is in die teenwoordigheid van mans (vgl Tannehill 1986:116; Green 1997:309). In 'n "quest" verhaal is daar altyd iets wat in die pad kom daarvan dat die persoon kry wat hy of sy soek. In hierdie geval is dit die Fariseër wat haar verwerp en op Jesus as profeet neersien omdat hy toelaat dat die vrou aan hom raak (Luk 7:39). Jesus verdedig haar en toon aanvaarding. Die Fariseër se houding word ontmasker deur 'n kort gelykenis. Die Fariseër, 'n persoon met status, word voorgehou as ongasvry en liefdeloos. Die sondige vrou, aan die ander kant, word geteken as iemand wat liefde betoon en korrek optree. Die rolle word omgekeer. Die Fariseër word uitgedaag "to reconsider the basis of his interaction with others, and thus the possibility not only of forgiving debts but also of having debts forgiven" (Green 1997:312). Die sondige vrou word herstel tot 'n nuwe lewe en ingesluit in die koninkryk van God.

In die Evangelie van Lukas en Handelinge neem vroue die inisiatief net soos mans. Terwyl Matteus in sy geboorteverhaal die klem op Josef laat val, plaas Lukas die klem op Maria (D’Angelo 1999b:181). Die ander karakters word voorgestel aan die hand van hulle verhouding met Maria. Maria se buite-egtelike swangerskap is ' $n$ dilemma in daardie kultuur. In Matteus is dit die man wat die probleem oplos. Hy neem die besluite. In Lukas is dit Maria se dilemma wat sý oplos deur haar eie keuses te maak.

Lukas voeg 'n paar vrouekarakters toe tot die materiaal wat hy van Markus oorneem (D’Angelo 1999b:181; kyk Parvy 1974:139-146). Byvoorbeeld, by Markus se lys manlike dissipels (Mark 3:13-19; Luk 3:12-16) voeg Lukas 'n lys vroulike dissipels (Luk 8:1-3). Lukas het twee geboorte-aankondigings: een aan Sagaria (Luk 1:67-79) en een aan Maria (Luk 1:46-56); daar is twee ouer mense in die tempel: Simeon en Anna. In die Sondergut van Lukas word baie meer karakters aangetref as 
in die ander evangelies. Voorbeelde is: die gebreklike vrou (Luk 13:10-17), Marta en Maria (Luk 10:38-42), die sondige vrou (Luk 7:36-50) (kyk D’Angelo 1999b:182).

Om hierdie redes word Lukas dikwels gesien as die evangelie vir vroue (kyk Maly 1980:99-104; Via 1987:38-55). Lukas romantiseer vroue egter nie. Seim se boek (1994), The double message: Patterns of gender in Luke-Acts, demonstreer die relativerende tendens in Lukas (vgl D’Angelo 1990:441-461; 1999b:181). Vroue word geskets as vennote van mans. Hulle is die gelyke ontvangers van God se genade. In Markus neem vroue die plek in van manlike dissipels wat faal. In Matteus word vroue in onder-steunende rolle geplaas. In Lukas is vroue aktiewe deelnemers gelykstaande aan mans. Hulle word nie gesien as "beter as mans" nie. Vroue word medewerkers wat ten volle deelneem aan God se geskiedenis met die wêreld. In die Evangelie van Lukas is mans én vroue soms aktief en neem die inisiatief. So ook is mans én vroue aan die ontvangkant van God se liefde en hulp.

Die storie van die kreupel vrou dien as 'n voorbeeld (Luk 13:10-17). Haar gebrek is veroorsaak deur 'n bose gees en sy was swak (Luk 13:11). Jesus as profeet is vervul met die Gees van God. Deur die krag van God word mense bemagtig. Die vrou wat deur Satan gebind was vir 18 jaar, word deur Jesus op die sabbatdag verlos (Luk 13:17). Jesus erken nie die verskil tussen heilige dae en gewone dae, soos die Fariseërs nie. Hy word aangedui (Luk 4) as die messiaanse profeet wat verlossing bring.

Lukas voeg 'n parallelle verhaal met 'n vrou as hoofkarakter by die gelykenis van die verlore skaap (Luk 14:8-10). 'n Vrou verloor een van haar 10 muntstukke, soek daarna en deel haar vreugde met haar buurvroue as sy dit kry. Hierdie gedeelte vorm deel van Jesus se reis van Galilea na Jerusalem. Die boodskap is: 'n mens moet weet wat jy opoffer om Jesus te volg (Luk 14:25-33). Wat 'n mens as waardevol beskou het, moet agtergelaat kan word. Gewoonlik sou mens dink dat 99 skape en 9 muntstukke meer waardevol is as een. Maar God se vreugde is groter wanneer een van die "minder-waardiges" gevind word. Man en vrou word in die gelykenis gebruik as voorbeeld van wat die nuwe lewe saam met Jesus behels.

Vroue is dikwels geromantiseer in die kerk en samelewing (vir "romantiese feminisme", kyk Osiek [1985] 1997:964, Massey 1985; Clark \& Richardson 1977:173-190). Vroue moet hiervolgens "hoër waardes" hê, "nader aan God" en "geesteliker" wees as mans, wat moet kompeteer in die wêreld. Die Evangelie van Lukas ondersteun nie die romantiese feminisme nie. Volgens Lukas is vroue en mans 
gelyk in wat hulle is en doen. Albei kan saggeaard wees. Albei is sondaars wat vergewe word deur God. Vroue en mans kan leiers wees en bydra om Jesus te versorg. Albei geslagte kan insien wat die evangelieboodskap werklik beteken. Mans en vroue is teenwoordig by die kruis en verstaan die sin van die gebeure. Vroue en mans sien die opgestane Heer en word getuies daarvan (Luk 24:22-23, 33-34). Vroue is nie ondergeskik nie en kan daarom nie uitgesluit word van volle deelname in die geloofsgemeenskap nie. Vroue en mans werk saam in kerk en samelewing.

\section{IMPLIKASIES}

Onderdrukkende Bybelstekste kan herlees word om hulle bevrydende potensiaal te ontdek (Schneiders 1989:3-9). Die doel is nie net om dinge beter te maak of meer geleenthede vir vroue te vind nie, maar eerder om waardes te verander (Rigsby 1994:39). "What women want is a world that offers more than two choices - male role, female role, and nothing else ... The ability to add new perceptions, purposes, and goals to the dynamics of social interaction is not something that the powerful expect from any of the weak; but the powerful are wrong" (Janeway 1980:13, 14). Wanneer vroue stilgemaak en misgekyk word in die kerk en gemeenskap, word nie net vroue geaffekteer nie. In die woorde van Poly Young-Eisendrath (1990:160) beïnvloed hierdie idees "all of us all of the time in the way that we expect the world and oursleves to be".

Wat feminisme na vore gebring het, is die fokus op 'n omvattende filosofie wat die volle persoonskap van vroue, die gelyke waarde van mans en vroue, en die openbare erkenning van vroue se waarde insluit. Navorsing het aangedui dat "the personal" en "the political" nie geskei kan word nie. Daar is 'n verskil tussen waardes wat afgedwing word op ondergeskikte groepe deur middel van die mag van heersende groepe en die waardes van hulle eie ervaring (vgl French 1985:442-444). Die ideaal is nie om 'n "plekkie" vir vroue in die samelewing te vind nie, maar dat samelewing verander sal word volgens die waardes van Jesus.

Feministiese interpretasie van die Bybel is krities ten opsigte van partriargale waardes wat vroue en ander benadeel. Volgens Jane Shaberg (1994:283) kan feministiese evangelienavorsing soos volg tot die studie van die historiese Jesus bydra:

In particular, on the question of the nature of the community of first followers of the historical Jesus, on the search for a Jesus who might have 
been at least welcoming to women, on the women in this movement, on the possibility of an "egalitarian moment", on the possibility of women's contribution to early Christian traditions.

Hierdie fokus op vroue en hulle rolle kan as self-gesentreerd beskou word. Aan die ander kant is 'n "objektiewe", belangelose benadering tot die interpretasie van die Bybel nie moontlik nie. Daarom is eerlikheid oor belange die aangewese weg. Die feministiese perspektief op die evangelies is nie net geïntereseerd in Jesus nie, maar ook in hoe Jesus met sy sosiale omgewing omgaan (kyk Shaberg 1994:284). Deur Jesus se interaksie met sy patriargale godsdienstige tradisie en samelewing te ondersoek, kan nie net die magte en kragte aan die werk in daardie samelewing beter verstaan word nie, maar ook dié van vandag. Op die manier dra vroue se interpretasie van die Bybel nie net by tot die besondere belange van vroue nie, maar ook tot die samelewing as geheel (vgl Graham 1995:124; Osiek 1997:958-959).

Navorsers het aangedui dat die Evangelie van Markus vroue hoofsaaklik in 'n positiewe lig sien, teenoor die twaalf manlike dissipels van Jesus wat veel negatiewer geteken word (Tolbert [1992] 1998:350). Daar is egter ook 'n minder positiewe kant aan die optredes van vroue in Markus. By die kruis hardloop die getroue vrou weg. En daar eindig die evangelie. Volgens Mary Ann Tolbert (1998:361-362) bring hierdie pynlike einde die punt van die evangelie tuis:

\footnotetext{
Ancient writing was intended to do things, to make people act or believe or change their behavior, not just to entertain them with a suitably concluded literary experience ... The expectations raised and then crushed by the end of the gospel are intended to move the hearers of the gospel into action ... At the end and indeed by means of the end itself, the audience of the Gospel of Mark, both women and men, are challenged to become themselves faithful disciples, carrying the message into the world, doing what some characters in the gospel have not proved worthy to do because of their subservience to social conventions or their desires for status, wealth, fame, or power.
}

In die Matteus-gemeenskap is vroue nie gesien as gelyke deelnemers nie. Die Evangelie van Matteus sluit egter vroue en ander uitgeslote persone by die geloofsgemeenskap in. Hulle word gelyke ontvangers van die liefde van God (vgl 
Levine [1992] 1998:340). Die enigste gelykenis in die Evangelie van Matteus wat 'n negatiewe waarde-oordeel uitspreek oor vrouekarakters, is die gelykenis van die wyse en dwase vroue. Levine (1998:348) herken die "misogynistic" implikasies van die gelykenis, maar meen tog dat Matteus die vroue in 'n positiewe lig sien. Die gelykenis lig die belangrikste temas van die evangelie uit: die doen van goeie werke, om jouself te gee vir Jesus, en gereed te maak vir die messiaanse feesmaal. Deur goeie werke en dus God se wil te doen, is om armes, die wat honger is en die wat in die tronk is, te help. Dit is wat Jesus gedoen het en wat die evangelie vroue en mans aanmoedig om ook te doen (Levine 1998:348).

Oor Lukas stel Jane Shaberg ([1992] 1998:363) dit skerp: “[T]he Gospel of Luke is an extremely dangerous text, perhaps the most dangerous in the Bible." Sy meen nie dat Lukas "vrou-vriendelik" is nie. Lukas trek wel heelwat vroue in in sy verhaal. Die stories waarin vroue die hoofrol speel, staan egter altyd in verband met 'n soortgelyke verhaal met 'n man in die hoofrol. Mans, aan die ander kant, tree onafhanklik van vroue op, veral waar dit gaan oor mag. Hoewel die Evangelie van Lukas 'n opmerklike poging aanwend om vroue te betrek, slaan Lukas se subjektiwiteit tog deur. Lukas rapporteer in die Emmaus-verhaal hoe verwarrend

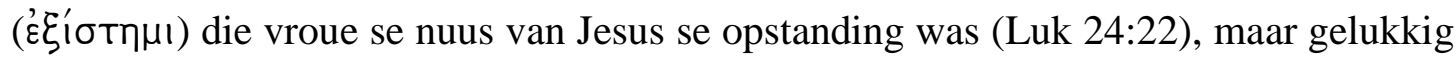
het die Here ook aan Simon verskyn (Luk 24:34). Dat 'n belangrike man hulle storie kon rugsteun, het geldigheid daaraan verleen. Volgens Shaberg (1998:363) lê die gevaar in die "subtle artistic power of the story to seduce the reader into uncritical acceptance of it as simple history, and into acceptance of the depicted gender roles as devinely ordained." Die bewuste poging van die evangelis om vroue in te sluit kan positief waardeer word. Aan die ander kant behoort gedeeltes in Lukas wat skadelik vir vroue is, noukeurig uitgewys te word. Dit is goed verskuil en nie maklik om raak te sien nie. As dit gedoen is, kan die teks se positiewe moontlikhede verder ontgin word. Egalitêre tradisies in die bronne wat Lukas gebruik het, die rol van God as hoofkarakter, God se doel vir die wêreld, Lukas se beskouing van armoede en weelde, kan help om 'n nuwe visie van 'n inklusiewe gemeenskap wat lyding sover moontlik wil uitskakel eerder as om dit te verheerlik, te vorm. "But enthusiasm for Luke-Acts ... is enthusiasm for a formidable opponent, not for an ally. Freedom in relation to this work is freedom to answer back, when the silenced find their voices" (Shaberg 1998:380). 
'n Noukeurig en kritiese lees van die Sinoptiese Evangelies kan help "[to] reframe our notions of what it means to be human" (Graham 1995:168). Dit kan bydra tot 'n wegbeweeg van 'n dualistiese model van bevoordeelde manlike dominansie en vroulike ondersteuning "towards a model of personhood that draws on new evaluative criteria" (Graham 1995:168).

\section{Literatuurverwysings}

Allison, D C 1984. "Elijah must come first". Journal of Biblical Literature 103, 256258.

Anderson, J C 1992. Feminist criticism: The dancing daughter, in Anderson, J C \& Moore, S D (eds), Mark \& method: New approaches in biblical studies, 103134. Minneapolis, MN: Fortress.

Anderson, J C 2001. Matthew: Gender and reading, in Levine, A-J (ed), A feminist companion to Matthew, 25-51. Sheffield: Sheffield Academic Press. (A Feminist Companion to the New Testament and Early Christian Writings 1.)

Best, E 1977. The role of the disciples in Mark. New Testament Studies 23, 377-401.

Best, E 1983. Mark: The gospel as story. Edinburgh: T \& T Clark. (Studies of the New Testament and its World.)

Bonz, M P 2000. The past as legacy: Luke-Acts and ancient epic. Minneapolis, MN: Fortress.

Bornkamm, G [1960] 1972. End-expectation and church in Matthew, in Bornkamm, G, Barth, G \& Held, H J, Tradition and interpretation in Matthew, translated by P Scott, 15-51. Second impression. London: SCM.

Bultmann, R [1921] 1963. History of the Synoptic tradition, translated by J Marsh. Revised edition. Peabody, MA: Hendrickson.

Carter, W 2000. Matthew and the margins: A socio-political and religious reading. Sheffield: Sheffield Academic Press. (JSNT Supplement Series 204.)

Carter, W 2001. Matthew and empire: Initial explorations. Harrisburg, PA: TrinityPress International.

Collins, J N 1990. Diakonia: Re-interpreting the ancient sources. Oxford: Oxford University Press.

Conzelmann, H [1954] 1973. Die Mitte der Zeit: Studien zur Theologie des Lukas. 7.Auflage. Tübingen: Mohr (Paul Siebeck).

D’Angelo, M R 1990. Women in Luke-Acts: A redactional view. Journal of Biblical Literature 109, 441-461. 
D’Angelo, M R 1999a. (Re)Presentation of women in the gospels: John and Mark, in Craemer, R S \& D’Angelo, M R (eds), Women \& Christian origins, 129-149. New York: Oxford University Press.

D’Angelo, M R 1999b. (Re)presentations of women in the Gospel of Matthew and Luke-Acts, in Kraemer, R S \& D'Angelo, M R (eds), Women \& Christian origins, 171-195. New York: Oxford University Press.

Davies, W D \& Allison D C [1988] 1997. A critical and exegetical commentary on the Gospel according to Saint Matthew, Vol 1: Introduction and commentary on Matthew I-VII. Latest impression. Edinburgh: T \& T Clark. (The International Critical Commentary on the Holy Scriptures of the Old and the New Testaments.)

Davies, M 1993. Matthew. Sheffield: JSOT Press. (Readings: A New Biblical Commentary.)

Dewey, J [1973] 1995. The literary structure of the controversy stories in Mark 2:13:6, in Telford, W R (ed), The interpretation of Mark, 141-152. Second edition. Edinburgh: T \& T Clark.

Dewey, J 1976. Disciples of the Way. New York, NY: Woman's Division, Board of Global Ministries, United Methodist Church.

Deutsch, C 2001. Jesus as Wisdom: A feminist reading of Matthew's Wisdom Christology, in Levine, A-J (ed), A feminist companion to Matthew, 88-133. Sheffield: Sheffield Academic Press. (A Feminist Companion to the New Testament and Early Christian Writings 1.)

Duling, D C 1978. The therapeutic Son of David: An element in Matthew's Christological apologetic. New Testament Studies 24, 392-410.

Duling, D C 1992. Matthew's plurisignificant “Son of David” in social science perspec-tive: Kinship, kingship, magic and miracle. Biblical Theology Bulletin 22, 99-116.

Esler, P F [1987] 1996. Community and gospel in Luke-Acts: The social and political motivations of Lucan theology. Reprinted. Cambridge, UK: Cambridge Univer-sity Press.

Fitzmyer, J A 1989. Luke the theologian: Aspects of his teaching. London: Geoffrey Chapman.

French, M 1985. Beyond power: On women, men and morals. New York: Summit. Geyser, A S 1956. The youth of John the Baptist: A deduction from the break in the parallel account of the Lucan infancy story. Novum Testamentum 1, 70-75. 
Goulder, M D 1989a. Luke: A new paradigm, Vol I: Part I. The argument. Part II. Commentary: Luke 1.1-9.50. Sheffield: Sheffield Academic Press. (Journal for the Study of the New Testament Supplement Series 20.)

Goulder, M D 1989b. Luke: A new paradigm, Vol II: Part II. (cont.). Commentary: Luke 9.51-24.53. Sheffield: Sheffield Academic Press. (Journal for the Study of the New Testament Supplement Series 20.)

Graham, E L 1995. Making the difference: Gender, personhood and theology. London: Mowbray.

Green, J B 1995. The theology of the Gospel of Luke. Cambridge: Cambridge University Press.

Green, J B 1997. The Gospel of Luke. Grand Rapids, MI: Eerdmans.

Held, H J [1960] 1972. Matthew as interpreter of the miracle stories, in Bornkamm, G, Barth, G \& Held, H J, Tradition and interpretation in Matthew, translated by P Scott, 165-299. Second impression. London: SCM.

Horsley, R A \& Silberman, N A 1997. The message and the kingdom: How Jesus and

Paul ignited a revolution and transformed the ancient world. New York: Grosset Putnam.

Howell, D B 1990. Matthew's inclusive story: A study in the narrative rhetoric of the

First Gospel. Sheffield: JSOT Press. (Journal for the Study of the New Testament Supplement Series 42.)

Humphries-Brooks S 2001. The Canaanite woman in Matthew, in Levine, A-J (ed), A feminist companion to Matthew, 138-156. Sheffield: Sheffield Academic

Press. (Feminist Companion to the New Testament and Early Christian Writings.)

Jackson, G S 2001. "Have mercy on me": The Canaanite woman in Matthew 15:21-

28. Sheffield: Sheffield Academic Press. (The Copenhagen International Seminar Series.)

Janeway, E 1980. Powers of the weak. New York: Knopf.

Kenney, W 1966. How to analyze fiction. New York: Monarch.

Kingsbury, J D 1975. Matthew: Structure, Christology, Kingdom. London: SPCK.

Kingsbury, J D 1981. Jesus Christ in Matthew, Mark, and Luke. Phildelphia, PA: Fortress. (Proclamation Commentaries.)

Kinukawa, H [1994] 2001. Women disciples of Jesus $(15.40-41 ; 15.47 ; 16.1)$, in Levine, A-J (ed), A Feminist companion to Mark, 171-190. Sheffield: Sheffield Academic Press. (Feminist Companion to the New Testament and Early Christian Writings 2.) 
Vroue in die Sinoptiese Evangelies - méér as dekoratiewe karakters

Klauck, H-J 1982. Die erzählerische Rolle der Jünger im Markusevangelium: Eine narrative Analyse. Novum Testamentum 24, 1-26.

Klostermann, E [1926] 1971. Das Matthäusevangelium. 4.Auflage. Tübingen: Mohr.

Knight, J 1998. Luke’s Gospel. London: Routledge.

Kuhn, H-W 1971. Ältere Sammlungen im Markusevangelium. Göttingen: Vandenhoeck \& Ruprecht.

Levine, A-J [1992] 1998. Matthew, in Newsom, C A \& Ringe, S H (eds), Women's Bible Commentary, 339-349. Expanded edition. Louisville, KY: Westminster.

Lohr, C H 1961. Oral techniques in the Gospel of Matthew. Catholic Biblical Quarterly 23, 403-435.

Mack, B L 1988. A myth of innocence: Mark and Christian origins. Philadelphia, PA: Fortress.

Malbon, E S 1983. Fallible followers. Women and men in the Gospel of Mark. Semeia 28, 29-48.

Malbon, E S 1986. Disciples/crowds/whoever: Marcan characters and readers. Novum Testamentum 28(2), 104-130.

Malbon, E S 1992. Narrative criticism: How does the story mean?, in Anderson, J C \& Moore, S D (eds), Mark \& method: New approaches in biblical studies, 2349. Minneapolis, MN: Fortress.

Malbon, E S [1982] 1995. Galilee and Jerusalem: History and literature in Marcan interpretation, in Telford, W R (ed), The interpretation of Mark, Second edition. Edinburgh: $\mathrm{T} \& \mathrm{~T}$ Clark.

Malbon, E S 2001. The poor widow in Mark and her poor rich readers, in Levine, A-J (ed), A feminist companion to Mark, 111-127. Sheffield: Sheffield Academic Press. (Feminist Companion to the New Testament and Early Christian Writings 2.)

Malina, B [1981] 1993. The New Testament world: Insights from cultural anthropology. Revised edition. Louisville, KY: Westminster.

Maly, E H 1980. Women and the Gospel of Luke. Biblical Theology Bulletin 10, 99104.

Marshall, I H [1970] 1992. Luke: Historian and theologian. Reprinted. Guernsey: The Paternoster Press.

Massey, M C 1985. Feminine soul: The fate of and ideal. Boston, MA: Beacon. 
Matera, F J [1988] 1995. The prologue as the interpretative key to Mark's gospel, in Telford, W R (ed), The interpretation of Mark, 289-306. Second edition. Edinburgh: T \& T Clark.

Minear, P S 1974. False prophecy and hypocrisy in the Gospel of Matthew, in Gnilka, J (Hrsg), Neues Testament und Kirche: Für Rudolph Schnackenburg. Freiburg: Herder.

Moltmann-Wendel E 1982. A land flowing with milk and honey: Perspectives on feminist theology, translated by J Bowden. New York: Crossroad.

Myers, C 1988. Binding the strong man: A political reading of Mark's story of Jesus. New York: Orbis Books.

Neusner, J 1973. From politics to piety. Englewood Cliffs, NJ: Prentice-Hall.

Osiek, C [1985] 1997. The feminist and the Bible: Hermeneutical alternatives. Hervormde Teologiese Studies 53(4), 956-968.

Parvey, C F 1974. The theology and leadership of women in the New Testament, in Ruether, R R (ed), Religion and sexism, 139-146. New York, NY: Simon and Schuster.

Pesch, R 1977. Das Markusevangelium, 1.Teil: Einleitung und Kommentar zu Kap. 1,1-8,26. 2.Auflage. Freiburg: Herder. (Herders Theologischer Kommentar zum Neuen Testament.)

Petersen, N R 1978. Literary criticism for New Testament critics. Philadelphia, PA: Fortress.

Reicke, B 1959. Instruction and discussion in the travel narrative. Studia Evangelica 1, 206-216.

Riches, J K 2000. Conflicting mythologies: Identity formation in the Gospels of Mark and Matthew. Edinburgh: T \& T Clark.

Rigsby, R K 1994. Jungians, achetypalist and fear of feminism, in Lawler, J G (ed), The 1994 Annual of Hermeneutics \& Social Concern, 35-58. New York, NY: Continuum.

Robbins, V K 1975. The we-passages in Acts and ancient sea voyages. Biblical Research 20, 5-18.

Robinson, J A T 1957-1958. Elijah, John and Jesus: An essay in detection. New Testament Studies 4, 263-281.

Rosenblatt, M-E 2001. Got into the party after all: Women's issues and the five foolish virgins, in Levine, A-J (ed), A feminist companion to Matthew, 171 195. Sheffield: Sheffield Academic Press. (A Feminist Companion to the New Testament and Early Christian Writings 1.) 
Vroue in die Sinoptiese Evangelies - méér as dekoratiewe karakters

Saldarini, A J 2001a. Absent women in Matthew's households, in Levine, A-J (ed), A feminist companion to Matthew, 157-170. Sheffield: Sheffield Academic Press. (A Feminist Companion to the New Testament and Early Christian Writings 1.)

Saldarini, A J [1988] 2001b. Pharisees, scribes and Saducees in Palestinian society: A sociological approach. Grand Rapids, MI: Eerdmans. (The Biblical Resource Series.)

Sanders, E P \& Davies M [1989] 1996. Studying the Synoptic Gospels. Fifth impression. London: SCM.

Schmithals, W. 1986. Das Evangelium nach Markus: Kapitel 9,2-16,18. Band 2/2. Gütersloh: Gütersloher Verlagshaus Gerd Mohn. (Ökumenischer Taschenbuch-Kommentar zum Neuen Testament 2/2.)

Schneiders, S M 1989. Feminist ideology criticism and biblical hermeneutics. Biblical Theology Bulletin 19, 3-9.

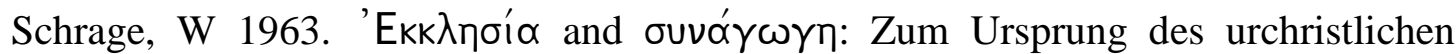
Kirchenbegriffs. Zeitschrift für Theologie und Kirche 60, 178-202.

Schüssler Fiorenza, E 1994. Jesus -Miriam's child, Sophia's prophet: Critical issues in feminist christology. New York: Continuum.

Scott, B B 1981. Jesus, symbol-maker for the kingdom. Minneapolis, MN: Fortress.

Seim, T K 1994. Patterns in gender in Luke-Acts. Edinburgh: T \& T Clark.

Sellin, G 1978. Komposition, Quellen und Funktion des lukanischen Reiseberichts (Luk IX.51-XIX.28). Novum Testamentum 20, 100-135.

Shaberg, J [1992] 1998. Luke, in Newsom, C A \& Ringe, S H (eds), Women's Bible Commentary, 363-380. Expanded edition. Louisville, KY: Westminster.

Shaberg, J 1994. (The) A feminist (contribution to) experience of historical Jesus scholarship, in Lawler, J G (ed), The 1994 Annual of Hermeneutics and Social Concern, 266-285. New York, NY: Continuum.

Swidler, L 1979. Biblical affirmations of women. Philadelphia, PA: Westminster.

Tannehill, R C 1986. The narrative unity of Luke-Acts, vol 1: The Gospel according to Luke. Philadelphia, PA: Fortress.

Tannehill, R C [1977] 1995. The disciples in Mark: The function of a narrative role, in Telford, W R (ed), The interpretation of Mark, 169-196. Second edition. Edinburgh: T \& T Clark.

Tatum, W B 1999. In quest of Jesus. Revised and enlarged edition. Nashville, TN: Abingdon. 
Thompson, W G 1970. Matthew's advice to a divided community: Matt 17:22-18:35. Rome: Biblical Institute.

Tiede, D L 1988. Glory to thy people, Israel: Luke-Acts and the Jews, in Tyson, J B (ed), Luke-Acts and the Jewish people, 21-34. Minneapolis, MN: Augsburg.

Tolbert, M A [1992] 1998. Mark, in Newsom, C A \& Ringe, S H (eds), Women's Bible Commentary, 350-362. Expanded edition. Louisville, KY: Westminster.

Tuckett, C 1983. The messianic secret. Philadelphia, PA: Fortress.

Van Aarde, A G 1994. God with us: The dominant perspective in Matthew's story. Pretoria: Gutenberg.

Via, D O 1975. Kerygma and comedy in the New Testament: A structuralist approach to hermeneutics. Philadelphia, PA: Fortress.

Via, E J 1987. Women in the Gospel of Luke, in King, U (ed), Women in the world's religions: Past and present, 35-55. New York: Paragon House.

Vorster, W S 1981. The function of the use of the OT in Mark. Neotestamentica 14, $62-72$.

Wainright, E M 1991. Towards a feminist critical reading of the Gospel according to Matthew. Berlin: De Gruyter. (BZNW 60.)

Wainright E M 2001. Not without my daughter: Gender and demon possession in Matthew 15.21-28, in Levine, A-J (ed), A feminist companion to Matthew, 126-137. Sheffield: Sheffield Academic Press. (Feminist Companion to the New Testament and Early Christian Writings.)

Wrede, W [1901] 1971. The messianic secret, translated by J C G Greig. London: James Clarke.

Wrede, W 1904. Zur Messiaserkenntnis der Dämonen bei Markus. Zeitschrift für Neutestamentliche Wissenschaft 5, 169-177.

Young-Eisendrath, P 1990. Rethinking feminism, the animus, and the feminine, in Zweig, C (ed), To be woman: The birth of the conscious feminine, 158-168. Los Angeles, CA: Tarcher. 